
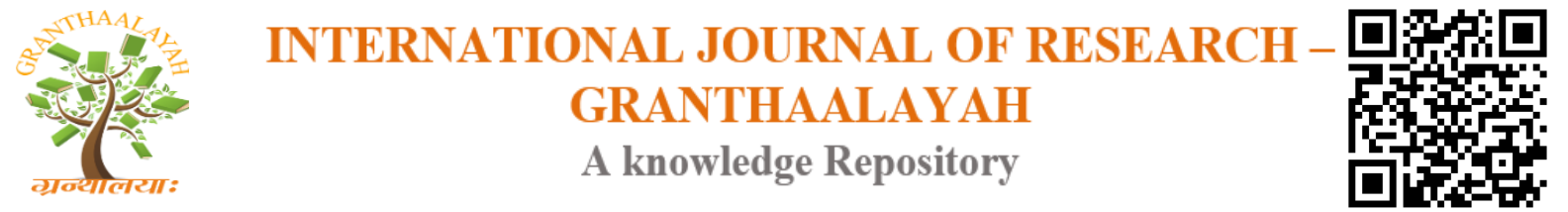

Science

\title{
ADAPTATION STUDY OF IMPROVED FODDER TREE (SESBANIA SESBAN (L.) MERRIL) AT HARO SABU, KELEM WOLLEGA, OROMIA, ETHIOPIA
}

\author{
Negasu Gamachu *1, Gizahu Wekgari ${ }^{1}$ \\ ${ }^{1}$ Oromia Agricultural Research Institute, Haro Sabu Agricultural Research Center, Haro Sabu, \\ Oromia, Ethiopia
}

\begin{abstract}
The experiment was conducted at Haro Sabu Agricultural Research Center, Western Oromia for two consecutive years, with the objective to identify adaptive, high yielding and disease/pest resistance varieties. Seven varieties were grown as experimental treatments in a randomized complete block design (RBCD) with three replications. Analysis revealed that DZ-96 and DZ-123 had maximum percentage of survival rate at one year age 0092 and 0347 completely died obtained from in one and two years age. Days of 50\% flowering showed statistically highly significant and Mean performance of plant height trait at different ages and seed yield were also significant $(\mathrm{p}<0.05)$. Mean green forage yield and Dry matter yield was not significantly $(\mathrm{p}<0.05)$ among treatments. But numerically difference was observed among treatments. Maximum fresh weight and sun-dried dry matter yield (DMY) were $84.43 \mathrm{t}$ ha-1 \& $27.64 \mathrm{t}$ ha-1 recorded from DZ- 96 followed by DZ-89 and DZ-123 with 18.91 \& 18.36 ton ha- 1 of sun dried DMY respectively. The best average seed yielders among the tested varieties were recorded from DZ-96 with 47.25 q ha1 followed by DZ-89 with 46.84 q ha-1. It is concluded that DZ- 96 and DZ- 89 were better performance varieties which are suitable for use as animal feeds.
\end{abstract}

Keywords: Sesbania Sesban; Dry Matter Yield; Seed Yield; Fodder Tree.

Cite This Article: Negasu Gamachu, and Gizahu Wekgari. (2019). “ADAPTATION STUDY OF IMPROVED FODDER TREE (SESBANIA SESBAN (L.) MERRIL) AT HARO SABU, KELEM WOLLEGA, OROMIA, ETHIOPIA.” International Journal of Research - Granthaalayah, 7(8), 212-219. https://doi.org/10.29121/granthaalayah.v7.i8.2019.661.

\section{Introduction}

Ethiopia is an agriculture based country where the majority of the population engage in subsistence level crop and livestock production (Nigussie, 2012), that is, mixed crop-livestock farming systems. Leguminous multi-purpose tree species provide a very important high-quality protein supplement for the crop residues and natural grassland which form the bulk of animal feed in subSaharan Africa. They have the added advantage of fixing nitrogen through their symbiotic 
relationship with Rhizobium, which can have considerable impact on soil fertility for the production of subsequent crops.

Among the multi-purpose tree species which have been the subject of research for use as animal feeds, Sesbania sesban has been found to provide a high-quality leaf material, which is of an equal quality to vetch hay when fed to small ruminants (ILCA, 1988). This species is indigenous to subSaharan Africa and is widely distributed throughout the region.

Fodder trees and shrubs offer considerable potential for use in mixed crop-livestock production systems to alleviate and complement the low feeding value of crop residues and natural pastures that constrain livestock production in sub-Saharan Africa (Devendra, 1992; Gutteridge and Shelton, 1994; Mekoya, 2008). Animals with access to fodder trees performed better than those kept on natural pasture in milk yield, weight gain, reproductive performances and survival rates (Elbasha et al., 1999; Mohamed-Saleem and de Leeuw, 1994; Norton, 1994). The effect of fodder trees can often be attributed to the supplementation of Nitrogen $(\mathrm{N})$ to the diet.

It is since 1970s that different exotic multipurpose fodder trees like Sesbania sesban got promoted by different organizations in Ethiopia to alleviate feed shortages (Mekoya et al., 2009b), maintain soil fertility and prevent land degradation. Sesbania is relatively well suited for highland areas when compared to other EMPFT such as Gliricidia, Calliandra and Leucaena (Mekoya et al., 2008). In a survey conducted in Ethiopia (Mekoya, unpublished) it was observed that 30 out of 32 governmental and non-governmental organizations engaged in agricultural development activities were promoting various accessions of Sesbania. S. sesban grows all over the subtropics in a wide variety of soils, and is one of the few nitrogen fixing forage trees that can grow in cooler highland regions in the tropics.

Sesbania [Sesbania sesban (L.) Merril.] Belongs to family Fabaceae (Manjusha et al., 2012) and is a multipurpose small stature tree (Nigussie \& Alemayehu, 2013). It is grown as a short duration perennial green manure (Mahmood et al., 2008), deep rooting shrub with high-quality foliage, and it serves as a protein supplement (Nigussie \& Alemayehu, 2013).

S. sesban can tolerate soil alkalinity and salinity to a considerable degree. Sesbania grows at altitude of between $100-2300 \mathrm{~m}$ where the average annual temperature is between $18-23^{\circ} \mathrm{C}$, and does not go below $10^{\circ} \mathrm{C}$ or above $45^{\circ} \mathrm{C}$ where the average annual rainfall is between $500-2000 \mathrm{~mm}$. Development of improved forages to improve livestock productivity is crucial. Livestock are an important part of the farming system of Kelem and West Wollega zone and one of the bottlenecks of livestock production is seasonality in quality and quantity of forage. Despite these positive attributes, livestock farmers in the study area are mainly dependent on grazing lands and crop residues and very little or no attention is given for improved forage species including fodder trees. Therefore, the study was undertaken the objective to identify and evaluate better adaptable, herbage and seed yield performance of some Sesbania sesban varieties. 


\section{Materials and Methods}

\section{Description of the Study Area}

The study was conducted on station at Haro sabu agricultural research center at latitude of $8^{\circ}$ 52'51' $\mathrm{N}$ and longitude $35^{\circ} 13^{\prime} 18^{\prime}$ ' E and altitude of $1515 \mathrm{~m}$ above sea level a plot of $4 \mathrm{~m} \times 3 \mathrm{~m}$ during 2008 and 2009 E.C. the center was located in western Ethiopia in Oromia region at $550 \mathrm{~km}$ from Finfine (Addis ababa). The average rain fall of the area is about $1000 \mathrm{~mm}$ and its distribution is uni-modal. Their maximum and minimum temperatures are $30{ }^{\circ} \mathrm{c}$ and $14^{\circ} \mathrm{c}$ respectively with average of $22{ }^{\circ} \mathrm{c}$. The area is characterized by coffee based farming system and crop-livestock mixed farming system (HSARC, 2012). The soil type of the experimental site is reddish brown with sandy loam in texture.

\section{Experimental Design and Plants}

Seven varieties were grown as experimental treatments to see adaptability in a Randomized Complete Block Design (RCBD) with three replications. A total of treatments like Dz-80, 0347, Dz-104, Dz-123, 0092, Dz-96 and Dz-89 were used.

\section{Plantation of the Fodder Plants and Growth Evaluation}

Plot size of each of the planted fodder plant was about $4 \mathrm{~m} \times 3 \mathrm{~m}\left(12 \mathrm{~m}^{2}\right)$. Planting materials of sesbania sesban were obtained from Debrezeit agricultural Research center. They were planted at spacing $1 \mathrm{~m}$ between rows and $50 \mathrm{~cm}$ between plants. The plants were weeded by hand to control the weed. Recommended fertilizer rate of $100 \mathrm{~kg} / \mathrm{ha}$ DAP were used during experimental period. The survival and growth of sesbania sesban varieties were attended for two years.

\section{Data Collected}

Data recorded were establishment date, survival rate, re generation percentage after pruning, disease/pest recorded, days of 50\% flowering, plant height, seed yield and biomass yield (total fresh weight \& dry matter (DM) yield).

\section{Statistical Data Analysis}

The data were subjected to statistical analysis of descriptive statistics and using SAS 9.1 computer software. Treatment means were compared using Least Significant Difference (LSD) test at 5\% level of probability.

\section{Results and Discussions}

\section{Percentage Germination and Survival}

The experiment started with seven (7) sesbania sesban varieties having 24 number of plant per plot. Data regarding percentage of germination and plant survival rate at different age was presented (table 1).

The seven tested varieties of Sesbania sesban were fully germinated (100\%). The survival rates were decline when the ages of plant was increase gradually and they were differences among varieties at 1 and 2 years age. At the ages of six months, all germinated plants were survived and they trends were similar to those shown for germination. 
At the age of one year old, the variety DZ-89 and DZ- 104 had maximum percentage of survival rate $(100 \%)$ i.e. (fully survived) followed by DZ-96 and DZ- 123 had 95.8\%, while minimum percentage survival rate of $71.5 \%$ and $75 \%$ per plot were recorded from 0092 and 0347 respectively.

Table 1: Percentage of plant Germination and survival at different ages

\begin{tabular}{|l|c|c|c|c|}
\hline Varieties & Germination \% & \multicolumn{3}{|c|}{ Survival rate \% } \\
\hline & & at 6 month & at 1 year & at 2 year \\
\hline DZ-80 & 100 & 100 & 91.6 & 47.2 \\
\hline DZ-89 & 100 & 100 & 100 & 50 \\
\hline DZ-96 & 100 & 100 & 95.8 & 59.7 \\
\hline DZ-104 & 100 & 100 & 100 & 48.6 \\
\hline DZ-123 & 100 & 100 & 95.8 & 52.7 \\
\hline 0092 & 100 & 100 & 71.5 & 0 \\
\hline 0347 & 100 & 100 & 75 & 0 \\
\hline
\end{tabular}

At the age of two (2) year, two varieties (0092 and 0347) were completely destroyed because of having annual (one year) life span or time. From the left five varieties, variety DZ- 96 had maximum percentage of survival rate $(59.7 \%)$ and had better performance than other varieties followed by DZ- 123 had 52.7\%, while others survived equal and less half of percentage of planted. Based on these result, the percentage of plant survive was declined when the life time of the plant was increased. This was because of wild animal cut roots of plant; they would dry during dry season.

\section{Plant Flowering and Growth (Height)}

Sesbania sesban was perennial improved fodder trees can flower to set seed. Table 2 shows Days at $50 \%$ flowering of different sesbania sesban varieties tested at HSARC during adaptation periods was highly significance difference between treatment at $(\mathrm{p}<0.05)$. Some tested varieties flowered early at 3.8 months (0347 and 0092 after planting while others took 5.9 to 6.8 months to flower. The result shows that from seven different adapted varieties, 0347 and 0092 varieties took short days 116 and 119 days respectively where as the long days of flowering was recorded 206.3 days from DZ-123 variety.

Table 2: Mean value of days to flowering and plant height of Sesbania sesban varieties tested on station for two years

\begin{tabular}{|l|c|c|c|c|}
\hline Varieties & DoF & PH 6mth $(\mathbf{c m})$ & PH 1 yr (cm) & PH 2 yr (cm) \\
\hline DZ-80 & $202.6^{\mathrm{a}}$ & $282.92^{\mathrm{c}}$ & $328.17^{\mathrm{b}}$ & $374.87^{\mathrm{c}}$ \\
\hline DZ-89 & $179.6^{\mathrm{b}}$ & $288.67^{\mathrm{c}}$ & $380^{\mathrm{a}}$ & $458.47^{\mathrm{ab}}$ \\
\hline DZ-96 & $204^{\mathrm{a}}$ & $277^{\mathrm{c}}$ & $371.42^{\mathrm{a}}$ & $477.8^{\mathrm{ab}}$ \\
\hline DZ-104 & $204^{\mathrm{a}}$ & $312.5^{\mathrm{a}-\mathrm{c}}$ & $363.67^{\mathrm{ab}}$ & $425.67^{\mathrm{bc}}$ \\
\hline DZ-123 & $206.3^{\mathrm{a}}$ & $307.5^{\mathrm{bc}}$ & $401^{\mathrm{a}}$ & $488.3^{\mathrm{a}}$ \\
\hline 0092 & $119^{\mathrm{c}}$ & $348.67^{\mathrm{a}}$ & $392.42^{\mathrm{a}}$ & - \\
\hline 0347 & $116^{\mathrm{c}}$ & $345.42^{\mathrm{ab}}$ & $376.42^{\mathrm{a}}$ & - \\
\hline CV & 4.3 & 7.14 & 5.93 & 6.7 \\
\hline Mean & 175.95 & 308.95 & 373.29 & 445.02 \\
\hline LSD & 13.48 & 39.28 & 39.38 & 56.21 \\
\hline
\end{tabular}

In each column, Means followed by different letters are significantly different $(\mathrm{P}<0.05)$; $\mathrm{DoF}=$ days of flowering, $\mathrm{PH}=$ plant height 
Plant height is a good indicator of growth rate and adaptation of a variety to the environment. The mean performance of Plant heights of different sesbania sesban varieties at different ages (6 month, 1year, and 2year) were studied during 2015 and 2016. The results indicated that, the differences among the means of the varieties for the plant height trait were significant at $(p<0.05)$ and presented (table 2).

At the age of 6 month, the plant heights were measured ranged from $277 \mathrm{~cm}$ in DZ-96 to $348.67 \mathrm{~cm}$ in 0092 . The result shows that from the tested varieties, higher plant height was obtained $348.67 \mathrm{~cm}$ from 0092 variety followed by $345.42 \mathrm{~cm}$ and $312.5 \mathrm{~cm}$ from 0347 and DZ-104 respectively where as short plant height was recorded $277 \mathrm{~cm}$ from DZ-96.

At the age of 1 year, the average plant height was $373.29 \mathrm{~cm}$ ranged from $328.1 \mathrm{~cm}$ in DZ-80 to $401 \mathrm{~cm}$ in DZ- 123. Varieties of DZ-123 produced the tallest plants $(401 \mathrm{~cm})$ while variety DZ-80 had the smallest plants $(328.1 \mathrm{~cm})$.

At the age of 2 year, the average plant height was $445.02 \mathrm{~cm}$. Varieties of DZ-123 had higher plant height than of other varieties. The plant height of sesbania sesban varieties at 2 years ranged from $374.87 \mathrm{~cm}$ in DZ- 80 to $488.3 \mathrm{~cm}$ in DZ- 123. The height of two varieties (0092 and 0347) was not measured because they were died due to had annual life span.

\section{Percentage of Plant Re-Growth}

Twelve number of plant sample per plot was pruned at age of one year on $75 \mathrm{~cm}$ height above the ground to see re-growth. From the tested varieties two varieties were not completely re-growth or re generated $(0 \%)$ because they are annual fodder tree type. Variety DZ-96 had maximum percentage of plant regenerated (83.3\%) followed by DZ-80 and DZ-123 had $77.5 \%$.

Table 3: Percentage of plant re-growth or re generate

\begin{tabular}{|l|c|c|c|}
\hline Varieties & NPP & NPR & \% of PR \\
\hline DZ-96 & 12 & 10 & 83.3 \\
\hline DZ-89 & 12 & 9 & 75 \\
\hline DZ-80 & 12 & 9.3 & 77.5 \\
\hline DZ-104 & 12 & 8 & 66.67 \\
\hline DZ-123 & 12 & 9.3 & 77.5 \\
\hline 0092 & 12 & 0 & 0 \\
\hline 0347 & 12 & 0 & 0 \\
\hline
\end{tabular}

$\mathrm{NPP}=$ No. of plant pruned, $\mathrm{NPR}=$ No. of plant regrowth, $\mathrm{PR}=$ plant regrowth

\section{Forage Biomass (Green and dry matter) yield}

Forages were harvested at 2 years old of plants and they collected from leaves and soft stems able to eat. Data regarding mean green forage yield (Fresh weight) and Dry matter yield was not significantly different between treatments at $(\mathrm{p}<0.05)$ and presented (table 4$)$. But, numerically difference was observed among varieties in the present study except the two (0092 and 0347) varieties. The highest fresh weight (green forage yield) was recorded from DZ- 96 of 84.43 tha $^{-1}$ followed by DZ- 123 of 59.44 tha $^{-1}$, while lower green forage yield (GFY) of 28.79 tha $^{-1}$ was recorded from DZ- 104. The fresh weight mean yield was 52.32 tha $^{-1}$. 
Amongst varieties, DZ- 96 produced maximum sun-dried dry matter yield (DMY) of 27.64 tha $^{-1}$, while minimum sun-dried DMY of 9.88 tha $^{-1}$ was recorded from DZ-104 (table 4). The dry matter mean yield of sun-dried obtained was 17.27 tha $^{-1}$ ranged from 9.88 tha $^{-1}$ for DZ- 104 to 27.64 tha 1 for DZ- 96. The previous studies reported on the dry matter yield of sesbania sesban, 20 ton/ha/year was recorded in Kenya (Wambugu et al., 2006) was lower than values recorded in variety DZ- 96 and which is comparable to the mean DMY of current study. In addition, According to the studies Dutt et al., 1983; Gore SB \&Joshi RN, 1976; Galang et al., 1990, the yield of $S$. sesban have ranged from 4 to 12 tonnes dry matter/ha/year depending upon location which is much lower to the current study. From seven adapted susbania susban varieties at Haro sabu agro ecologies, DZ-96 produced the higher dry matter yield and had better performance followed by DZ-89 and DZ-123 respectively.

Table 4: Mean value of wet and dry leafy biomass (ton/ha) and seed yield of sesbania sesban varieties tested at Haro sabu agricultural research center (on station) for two years

\begin{tabular}{|l|c|c|c|}
\hline Varieties & FWY (ton/ha) & DMY (ton/ha) & SY (q/ha) \\
\hline DZ-80 & $32.21^{\mathrm{b}}$ & $11.54^{\mathrm{b}}$ & $15.77^{\mathrm{d}}$ \\
\hline DZ-89 & $57.76^{\mathrm{ab}}$ & $18.91^{\mathrm{ab}}$ & $46.84^{\mathrm{a}}$ \\
\hline DZ-96 & $84.43^{\mathrm{a}}$ & $27.64^{\mathrm{a}}$ & $47.25^{\mathrm{a}}$ \\
\hline DZ-104 & $28.79^{\mathrm{b}}$ & $9.88^{\mathrm{b}}$ & $35.96^{\mathrm{ab}}$ \\
\hline DZ-123 & $59.44^{\mathrm{ab}}$ & $18.36^{\mathrm{ab}}$ & $28.86^{\mathrm{bc}}$ \\
\hline 0092 & - & - & $19.26^{\mathrm{cd}}$ \\
\hline 0347 & - & - & $19.83^{\mathrm{cd}}$ \\
\hline CV & 40.62 & 39.59 & 21.65 \\
\hline Mean & 52.32 & 17.27 & 30.54 \\
\hline LSD & 40.02 & 12.87 & 11.76 \\
\hline
\end{tabular}

FWY = fresh weight yield, DMY= dry matter yield, $\mathrm{SY}=$ seed yield

\section{Seed Yield}

Seed yield was significantly different between treatments at $(\mathrm{p}<0.05)$. Seed yield was collected in both years. Mean seed yield was 30.54 ton/ ha. The best average seed yielders among the tested Sesbania susban varieties were recorded from DZ-96 with $47.25 \mathrm{q} \mathrm{ha}^{-1}$ followed by DZ-89 and DZ-104 with 46.84 and 35.96 qha $^{-1}$ while the yield of DZ-80 was lower than all varieties with $15.77 \mathrm{q} \mathrm{ha}^{-1}$.

\section{Incidence of Insect Pest Resistance}

In all Variety tested insect pest was seen during rainy season or months (April to August) and did not pose any serious problem. According data recorded shows variety DZ-96 and DZ-89 were moderately resistance than other varieties tested.

\section{Conclusion and Recommendation}

The performance of Sesbania sesban was tested under Haro Sabu midland climates of Kellem Wollega zone of Oromia regional state. From this study, it can be concluded that among the tested fodder tree (Sesbania sesban) varieties collected from Debrezeit Agricultural Research Center, DZ-96 and DZ-89 have greater performances in terms of their high forage herbage dry matter yield, seed yield and better agronomic parameters. Also they are suitable for use as animal feeds under the study area. As a result, to recommend that these two varieties were suitable at this area 
and better to popularize and demonstrate this technology reaches farmers and animal producers (end users) better to use for their livestock mix with poor quality (low protein content) as feed resources to enhance animal products.

\section{Acknowledgements}

The authors acknowledgements the Oromia Agricultural research institute for funding.

\section{Appendices}

Appendix A: Combined analysis of variance (ANOVA) of days of flowering, plant height, dry matter and seed yield of tested Sesbania sesban

\begin{tabular}{|l|c|c|c|c|c|c|c|}
\hline $\begin{array}{l}\text { Source of } \\
\text { variance }\end{array}$ & DoF & $\begin{array}{c}\text { PH 6 } \\
\text { months }\end{array}$ & PH 1yr & PH 2yr & FWY & DMY & SY \\
\hline Trt & $5030.82 * *$ & $2515.94 *$ & $1660.35^{*}$ & $6320.57 *$ & $1587.96 \mathrm{~ns}$ & $149.04 \mathrm{~ns}$ & $518684.878^{*}$ \\
\hline Rep & 37.47 & 3858.58 & 3106.51 & 18501.63 & 4088.53 & 42343 & 1261493.63 \\
\hline Error & 57.42 & 487.54 & 490.22 & 891.33 & 451.86 & 46.77 & 437449.44 \\
\hline
\end{tabular}

*= significance $\quad \mathrm{ns}=$ non significance

$\mathrm{DoF}=$ days of flowering, $\mathrm{PH}=$ plant height, $\mathrm{FWY}=$ fresh weight yield, DMY= dry matter yield, $\mathrm{SY}=$ seed yield

\section{References}

[1] Devendra, C. Nutritional potential of fodder trees and shrubs as protein sources in ruminant nutrition. 1992

[2] Dutt AK, Pathania U, Kumar V. Growth of Sesbania sesban. Nitrogen Fixing Tree Res. Rep. 1983; 1:5-6

[3] Elbasha,E., Thornton,P.K., Tarawali,G. .An ex-post economic impact assessment of planted forages in West Africa. ILRI Impact Assessment Series. ILRI (International Livestock Research Institute), Nairobi, Kenya, 1999; p. 68.

[4] Galang MC, Gutteridge RC, Shelton HM. The effect of cutting height and frequency on the productivity of Sesbania sesban var. Nubica in a sub-tropical environment. Nitrogen Fixing Tree Res. Rep. 1990; 8:161-164.

[5] Gore SB, Joshi RN. Effect of fertilizer and frequency of cutting on the extraction of protein from Sesbania. Indian J Agron. 1976; 21:39-42.

[6] Gutteridge, R.C., Shelton, H.M. The role of forage tree legumes in cropping and grazing systems. 1994

[7] ILCA (International Livestock Centre for Africa). ILCA Annual Report 1988. ILCA, Addis Ababa, Ethiopia. 1988.

[8] Mahmood, A., M. Athar, R. Qadri and N. Mahmood. Effect of $\mathrm{NaCl}$ salinity on growth, nodulation and total nitrogen content in Sesbania sesban. Agric. Conspectus Sci., 2008; 73(3): 137-141.

[9] Manjusha, N. Aggarwal, Nitesh and P. Gupta. Effect of petroleum ether extract of Sesbania sesban (Merr.) roots in streptozotocin (STZ) induced diabetes in mice. Asian Pac. J. Tropic Biomedic., S: 2012; 1254-S1260.

[10] Mekoya, A. Multipurpose fodder trees in Ethiopia. Farmers' perception, constraints to adoption and effects of long term supplementation on sheep performance. PhD-thesis, Wageningen University, Animal Production Systems Group, The Netherlands. 2008.

[11] Mekoya, A.,Oosting,S.J., Fernandez-Rivera,S., vander Zijpp, A.J.

Farmers' perceptions about exotic multipurpose fodder trees andconstraints to their adoption. Agroforest. Syst. ,2008; 73, 141-153 
[12] Mekoya A, Oosting SJ, Fernandez-Rivera S, Tamminga S, Van der Zijpp AJ. Effect of supplementation of Sesbania sesban to lactating ewes on milk yield and growth rate of lambs. (2009b).

[13] Mohamed-Saleem, M.A., deLeeuw, P.N. Stylo-based pasture development for agropastoral production systems .1994.

[14] Nigussie, Z. and G. Alemayehu. Potential uses of an underutilized multipurpose tree in Ethiopia. Afr J. Plant Sci., 2013; 7(10): 468-475.

[15] Norton, B.W., Tree legumes as dietary supplements for ruminants. In: Gutteridge, R.C., Shelton, H.M. (Eds.), Forage Tree Legumes in Tropical Agriculture. CAB International, Wallingford, UK, 1994; pp. 192-201.

[16] Wambugu, C., Franzel, S., Cordero, J. \& Stewart, J. Fodder shrubs for dairy farmers in East Africa: making extension decisions and putting them into practice. World Agroforestry Centre, Nairobi, Kenya; Oxford Forestry Institute, Oxford, U.K 2006; 172 pp.

\footnotetext{
*Corresponding author.

E-mail address: negasugamachu@ gmail.com
} 